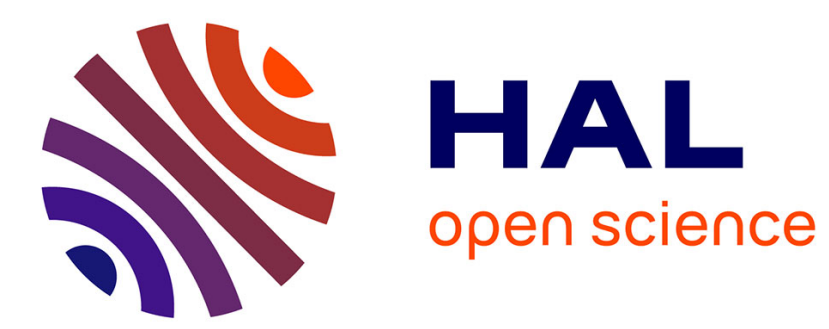

\title{
The Excess Demand for Subsidized Child Care in Germany
}

Katharina Wrohlich

\section{To cite this version:}

Katharina Wrohlich. The Excess Demand for Subsidized Child Care in Germany. Applied Economics, 2008, 40 (10), pp.1217-1228. 10.1080/00036840600771288 . hal-00582008

\section{HAL Id: hal-00582008 \\ https://hal.science/hal-00582008}

Submitted on 1 Apr 2011

HAL is a multi-disciplinary open access archive for the deposit and dissemination of scientific research documents, whether they are published or not. The documents may come from teaching and research institutions in France or abroad, or from public or private research centers.
L'archive ouverte pluridisciplinaire HAL, est destinée au dépôt et à la diffusion de documents scientifiques de niveau recherche, publiés ou non, émanant des établissements d'enseignement et de recherche français ou étrangers, des laboratoires publics ou privés. 


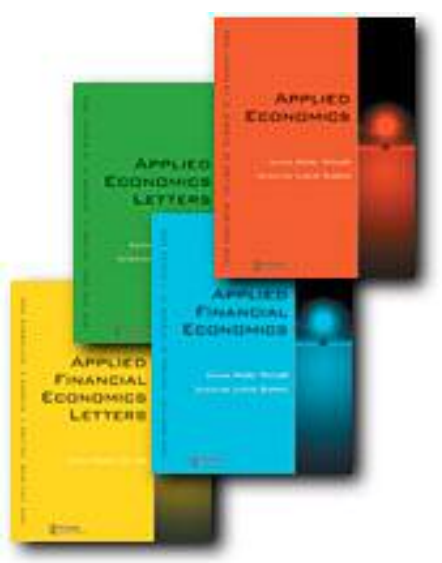

The Excess Demand for Subsidized Child Care in Germany

\begin{tabular}{|r|l|}
\hline Journal: & Applied Economics \\
\hline Manuscript ID: & APE-05-0679.R1 \\
\hline Journal Selection: & Applied Economics \\
\hline JEL Code: & $\begin{array}{l}\text { C35 - Discrete Regression and Qualitative Choice Models < C3 - } \\
\text { Econometric Methods: Multiple/Simultaneous Equation Models < C - } \\
\text { Mathematical and Quantitative Methods, J13 - Fertility|Family } \\
\text { Planning|Child Care|Children|Youth < J1 - Demographic Economics } \\
\text { < - Labor and Demographic Economics, D12 - Consumer } \\
\text { Economics: Empirical Analysis < D1 - Household Behavior and } \\
\text { Family Economics < D - Microeconomics }\end{array}$ \\
\hline Keywords: & child care, excess demand, partial observability model \\
\hline
\end{tabular}




\title{
THE EXCESS DEMAND FOR SUBSIDIZED CHILD CARE IN GERMANY
}

\author{
Katharina Wrohlich, DIW Berlin and IZA Bonn
}

(This version: 11/04/2006)

\begin{abstract}
:
The extension of publicly provided or subsidized child care is currently one of the priorities of the political agenda in many European countries. In this paper the excess demand for subsidized child care slots in Germany is estimated using a partial observability model. The results show that there is considerable excess demand for child care for children aged less than three years in east and west Germany, even among children with working mothers.
\end{abstract}

Key-Words: child care, excess demand, partial observability model

JEL Classification: J13, C35, D12

\section{Correspondence to:}

Katharina Wrohlich

German Institute for Economic Research (DIW Berlin)

Koenigin-Luise Str. 5

14195 Berlin, Germany

e-mail: kwrohlich@diw.de

phone: +493089789164

fax: +493089789114 


\title{
THE EXCESS DEMAND FOR SUBSIDIZED CHILD CARE IN GERMANY
}

(This version: 11/04/2006)

\begin{abstract}
:
The extension of publicly provided or subsidized child care is currently one of the priorities of the political agenda in many European countries. In this paper the excess demand for subsidized child care slots in Germany is estimated using a partial observability model. The results show that there is considerable excess demand for child care for children aged less than three years in east and west Germany, even among children with working mothers.
\end{abstract}

Key-Words: child care, excess demand, partial observability model

JEL Classification: J13, C35, D12 


\section{Introduction}

Providing suitable child care services has become an important political objective in many European countries. While child care policy has long been a neglected issue, policy makers now see subsidized child care as a multiple-purpose policy instrument that is hoped to affect mothers' labor force participation, fertility and educational outcomes. The importance of child care has also been recognised on the level of the European Union. At the Barcelona summit of the European Council in 2002, EU member states agreed upon harmonized child care targets: By 2010, member states shall be providing child care to at least 90 percent of children between three years and mandatory school age and at least 33 percent of children under three years of age, "taking into account the demand for child care facilities and in line with national patterns of provision". 1

While several countries in the EU already fulfil these targets, many continental and southern European countries are falling behind, as can be seen from Figure 1. Germany is also among these countries. However, the German case is somewhat special: while the provision of child care is high in all parts of east Germany, provision of child care for children below three years in west Germany is among the lowest in Europe. Recently, the German government has introduced legislations that aim at a "demand-oriented" extension of subsidized child care in Germany, especially for children under the age of three years.

[Figure 1 about here]

On the European, as well as on the national level, there seems to be the political goal of extending subsidized child care in order to meet the demand. In the

\footnotetext{
${ }^{1}$ See Plantenga (2004).
} 
presence of rationing, however, estimating demand for child care is not trivial. For Germany, micro level data sets with information on explanatory variables necessary to estimate demand for child care, such as the Labour Force Survey (Mikrozensus) or the Socio-Economic Panel (SOEP), only include information on child care utilization, not on child care demand. It is known whether a child is in a child care facility, but if this is not the case, one does not know whether this is because his or her parents did not want the child to attend a child care facility, or whether they applied for a slot but were not offered one. To identify demand and supply of child care services, partial observability models such as those introduced by Poirier (1980) and Abowd and Farber (1982) and applied to the context of child care in the UK by Chevalier and Viitanen (2004) can be used. These models allow estimating the demand for and supply of child care even when only the joint outcome of these two variables, namely child care utilization, is observed.

For the purpose of estimating demand for child care in Germany, I will use a model that combines the advantages of the model by Poirier (1980) and the Abowd and Farber (1982) model. Since it is known that, for institutional reasons, certain children are not restricted in their access to child care facilities, the sample can be divided into two parts: first, observations which are not restricted and secondly observations which might be restricted. Thus, the estimation of demand and supply of child care slots is based on a likelihood function that consists of two parts, a univariate probit of the demand for child care for the unrestricted part and a bivariate probit of demand and supply of child care for the possibly restricted part of the sample.

Estimation results show that among children aged up to three, a large fraction of children are queuing for child care ( 24 percent in west Germany and 59 percent in east Germany), i.e. their parents demand a child care slot but are not offered one. 
Even though availability of child care is higher in east than in west Germany, the excess demand for child care is larger in east Germany since the demand for child care is well above the national average in these regions. For children between three and six years, access restrictions to child care do not seem to be a major problem.

The reminder of the paper is organized as follows: The next section provides some stylized facts on utilization and availability of child care and a short description of the child care "market" in Germany. Section 3 gives a short overview of the relevant literature. In Section 4 the details of the econometric model are presented, while Section 5 describes the data. In Section 6, the estimation results are presented, Section 7 summarizes and concludes.

\section{Stylized Facts and Institutional Setting}

Official statistics show that in Germany, availability of child care, usually measured as slots per 100 children in a certain age group, differs between regions and age groups (see Table 1). Overall, availability of child care is much higher in east than in west Germany, especially for the younger age group. This is due to the fact that women's employment (including mothers' employment) was strongly encouraged in the former German Democratic Republic, whereas in west Germany, policy discouraged mothers from working. ${ }^{2}$

Given the data on child care availability, it is not surprising that also child care utilization differs considerably between east and west Germany and between children younger than three years and children between three years and school age. ${ }^{3}$

\footnotetext{
${ }^{2}$ See Rosenfeld et al. (2004) for a detailed description of women's employment patterns in the two German states before reunification.

${ }^{3}$ Official statistics show that on average, there are 3 slots available for 100 children under the age of three. On the other hand, 6 percent of all households with children under three years in the SOEP report that their child is in a child care facility. This difference might be due to the fact that some facilities take more children than they are officially allowed to. Another explantion would be that some children are in a form of child care that is "instiutional" but not counted by official statistics.
} 
The same pattern applies to the employment rates of mothers. ${ }^{4}$ Employment among mothers in east Germany is higher than employment among mothers in west Germany, and employment increases with the age of the child.

[Table 1 about here]

Another interesting fact is that the correlation between maternal employment and child care utilization in Germany is not as strong as it could be expected. Among all children aged between three and six who are in a child care facility, only about 40 percent have working mothers. The figure is somewhat higher (about 60 percent) for children under three years using child care services. In general, the relatively low employment rate of German mothers can be related to the negative work incentives that result from joint income taxation (see Steiner and Wrohlich (2004)) and the generous parental leave scheme (see Lauer and Weber (2003)). The relatively low employment rate of mothers with children in child care institutions is more puzzling and could be explained by the fact that in west Germany, child care, especially parttime care for children aged between three and six years, is primarily seen as preschool education and not necessarily as a means to facilitate mothers' employment. On the other hand, 17 percent of all children under three, who are not in child care, have working mothers. It is to be assumed that in this case some sort of informal

This might particularly be the case in the growing sector of family day care, which is increasingly also subsidized by communities but not counted as slots in child care facilities in the official statistics. Note that child care by private babysitters or childminders is not counted as "in child care" in this table.

\footnotetext{
${ }^{4}$ The reason why in this analysis, the focus is on child care and mother's employment and other characteristics of the mother is the fact that in Germany, in the large majority of all families, housework and child care is still undertaken by the mother and not the father (see, e.g., Steinbach 2004).
} 
child care - either by the father, grandparents, neighbours etc. or paid babysitters - is used.

The "market" for formal child care is highly regulated in Germany. ${ }^{5}$ Formal child care is highly subsidized, such that parents' fees only cover about 25 percent of the total costs. Parents' fees are charged according to the parents' income. Admission to child care institutions is regulated through the communities. The usual practice is to favour children with working parents, children with single mothers and children with older siblings who are in the same institution.

In addition to public or private facilities, child care by nannies or childminders is also used, especially for children under the age of three. This sector has traditionally been almost exclusively privately organized, and official statistics about the amount of utilization of child minding in terms of children or hours, as well as on the cost structure, are not available. Estimations based on surveys give utilization of full-time babysitters or child minders of about $4 \%$ of all children under the age of three. The costs of child care by a childminder are much higher than in a child care facility, and amount to about 690 Euro per month (Jurczyk et al. 2004). In contrast, parents' fees for a full-time slot in a subsidized child care facility amount to 110 Euro on average. The highest fee reported by parents in the SOEP wave 2002 amounts to 400 Euro per month.

Given that this private market for child care in the form of child minding exists, excess demand for child care really means excess demand for child care at the subsidized price, i.e. in subsidized child care facilities. Considering the large difference between the market price for child care and the parents' fees for a subsidized child care slot, it is not surprising that parents prefer to queue for a subsidized child care slot instead of buying private child care on the market, since the

\footnotetext{
${ }^{5}$ For a detailed description of Germany's child care institutions see Ewers et. al. (2005)
} 
costs might exceed the mother's (or father's) market wage ${ }^{6}$. Therefore, it is important to keep in mind throughout the paper that by excess demand for child care I really mean the excess demand for child care in subsidized institutions. ${ }^{7}$

\section{Literature Review}

The demand for child care has already been subject of numerous international studies. There exists a large literature on the demand for child care in the United States and Canada (see, among others, Connelly and Kimmel (2003), as well as Joesch and Hiedemann (2002), who provide a detailed literature review), and more recently also for other countries. ${ }^{8}$ In most of these studies, demand for child care and labour supply decisions of mothers is estimated simultaneously. Some other studies focus on special characteristics of the demand for child care. For example, Joesch and Hiedemann (2002) estimate the demand for child care using a double-hurdle model in order to separate different reasons for zero child care consumption in the US. While they differentiate between zero consumption due to high costs and zero consumption because parents are not interested in non-relative child care regardless of the cost, access restrictions to child care are not modelled as a reason for zero consumption. Access restrictions are explicitly modelled by Chevalier and Viitanen (2004) in a study of the demand for child care in the UK. The authors use a partial observability model in the style of Porier (1980) in order to separate demand and supply of child care. They find evidence for considerable excess demand for child care in the UK.

\footnotetext{
${ }^{6}$ There might of course be also other reasons why parents prefer institutional child care over the private sector, for example if they expect the child care quality to be higher in the institutional sector. However, due to lack of data, quality issues are not taken into account in my analysis.

${ }^{7}$ The question of why an excess demand exists in the child care market, and whether the supply of child care is endogenous with respect to mothers' employment rates is not analyzed in this paper. Stutzer and Duersteler (2005) provide an interesting investigation of this question for the case of Switzerland.

${ }^{8}$ See e.g. Choné et al. (2003) for France, Del Boca et al. (2004) for Italy, Kornstad and Thorensen (2006) for Norway, Lokshin (2004) for Russia.
} 
As far as Germany is concerned, the empirical literature on the demand for child care is rather limited. ${ }^{9}$ An early study by Merkle (1994), who uses data from the SOEP, estimates price elasticities for child care demand. Ondrich and Spieß (1998) analyze the determinants of the transition from home to institutional child care in Germany. Büchel and Spieß (2002) estimate the effects of socio-economic variables such as education and income as well as parents' ethnicity on the utilization of child care on basis of the SOEP. Although e.g. Merkle (1994) and Ondrich and Spieß (1998) "control" for rationing of child care slots in the demand estimation by introducing the availability of child care slots on a regional level as a control variable, these studies are either based on the assumption that observed child care utilization can be interpreted as demand or explicitly state that effects on child care utilization are estimated. In the latter case, these studies have no implication concerning the demand for child care.

\section{Econometric Model}

The data set I use for estimation contains information about the child care status of the child, i.e. it is known if a child is in a child care facility or not. If a child is not in a child care facility, this can be the case because (i) the parents do not want the child to be in a child care facility, or (ii) because the parents applied for a child care slot but were not offered a slot. This implies that the observed variable "child care status" is in fact the joint outcome of two unobserved variables, namely the demand for child care and the supply of child care slots. In order to calculate the size of the queue for subsidized child care, a model has to be estimated that allows to predict the probability that a child is not given a child care slot (supply $=0$ ), although the parents want the child to be cared for in a facility (demand $=1$ ). On the basis of

\footnotetext{
${ }^{9}$ A detailed literature survey on German studies can be found in Büchel and Spieß (2002).
} 
partial observability models, demand and supply for a restricted good can be estimated, even if only the joint outcome of the two unobserved variables, demand and supply, is observed.

Formally, the model can be stated as follows: The latent variable demand for child care $D^{*}$ depends on child and household characteristics $X_{D}$ and a stochastic part $\varepsilon_{D}$

$$
D^{*}=X_{D} \beta_{D}+\varepsilon_{D}
$$

where $\beta_{D}$ is a vector of coefficients. It will be assumed that parents will have realized demand if $D^{*}$ is above a certain threshold, which is set to zero for convenience,

$$
D=1 \text { if } D^{*}>0
$$

Therefore, the probability that parents demand institutional child care can be stated as

$$
\operatorname{Pr}(D=1)=\operatorname{Pr}\left(\varepsilon_{D}>-X_{D} \beta_{D}\right)
$$

Further, it is assumed that parents are offered a child care slot according to some household, child and regional characteristics $X_{S}$, a vector of coefficients $\beta_{S}$ and a stochastic error term $\varepsilon_{S}$, formally

$$
S^{*}=X_{S} \beta_{s}+\varepsilon_{s}
$$

As in the case of the observed demand a child care slot will be supplied for a certain child if $S^{*}$ is above zero, 


$$
S=1 \text { if } S^{*}>0
$$

Thus, the probability of having a child care slot available is

$$
\operatorname{Pr}(S=1)=\operatorname{Pr}\left(\varepsilon_{S}>-X_{S} \beta_{S}\right)
$$

As already mentioned above, only the joint outcome of the two variables $D$ and $S$, namely child care utilization $C$, is observed. The probability that child care is used is

$$
\operatorname{Pr}(C=1)=\operatorname{Pr}(S=1 \cup D=1)=\operatorname{Pr}(D=1) \cdot \operatorname{Pr}(S=1 \mid D=1) .
$$

Poirier (1980) proposed to estimate the parameters of $\beta_{D}$ and $\beta_{S}$ in a bivariate probit model that is identified if each equation excludes at least one exogenous variable appearing in the other equation. The likelihood function of this model is given as

$$
L=\Pi\left[\Phi_{2}\left(X_{D} \beta_{D}, X_{S} \beta_{S} ; \rho\right)\right]^{C} \cdot\left[1-\Phi_{2}\left(X_{D} \beta_{D}, X_{S} \beta_{S} ; \rho\right)\right]^{1-C}
$$

where $\Phi_{2}$ denotes the bivariate normal cumulative distribution function.

This model was used for a joint estimation of demand and supply of child care slots in the UK by Chevalier and Viitanen (2004). In the German case, however, some children are not restricted in their access to child care services. Children who have already been in a child care facility the year before do not have to queue again for a slot in the current year. The data set I use (SOEP) is a panel study, thus information on last year's child care status is available. Secondly, I will assume that 
all children who live in a county where availability of child care slots is near to hundred percent in their age group are also part of the unrestricted sample. ${ }^{10}$ Drawing on this information, I follow the idea of Abowd and Farber (1982) and divide the sample into two parts, namely the unrestricted observations and the possibly restricted observations. For the unrestricted part, the observed variable "child care utilization" can be explained by demand-side variables only. The likelihood function of the model used here therefore consists of two parts: a univariate probit part for the unrestricted sample and a bivariate probit for the restricted sample. Assuming that the coefficients of the demand variables are the same in both parts, the likelihood function of this model takes the following form:

$$
\begin{aligned}
& L=\prod_{N R=1} \Phi\left(X_{D} \beta_{D}\right)^{C}\left[1-\Phi\left(X_{D} \beta_{D}\right)\right]^{1-C} . \\
& \prod_{N R=0}\left[\Phi_{2}\left(X_{D} \beta_{D}, X_{S} \beta_{S} ; \rho\right)\right]^{C} \cdot\left\{1-\left[\Phi_{2}\left(X_{D} \beta_{D}, X_{S} \beta_{S} ; \rho\right)\right]\right\}^{1-C}
\end{aligned}
$$

where $N R=1$ denotes the unrestricted sample and $N R=0$ denotes the possibly restricted sample. ${ }^{11}$ Note that identification of the model stated in equation (9) is based on exclusion restrictions as well as the estimation of a univariate probit for the unrestricted part of the sample.

Apart from the coefficients, I am particularly interested in the probability that demand equals 1 , but supply equals 0 , i.e. $\operatorname{Pr}(D=1 \cup S=0)$. When grossed up to the population total, this can be interpreted as excess demand for subsidized child care in Germany.

\footnotetext{
${ }^{10}$ There are 440 counties in Germany. It is assumed that children are not restricted in their access to child care slots if there are more or equal to 99 slots per 100 children in the county.

${ }^{11}$ Note that this likelihood function is not the same as the one used by Abowd and Farber (1982). In their application, demand and supply of the possibly restricted part of the sample is specified as the product of the two corresponding probabilities rather than a bivariate distribution.
} 
The variables used in both the demand $\left(X_{D}\right)$ and the supply equation $\left(X_{S}\right)$, are the age of the child, the mother's marital status and number of siblings in child care facilities. Mother's nationality is also included in both equations, since both, demand patterns as well as the ability to overcome the access restrictions to subsidized child care may differ between Germans and non-German citizens.

The variables that are included in the demand equation only are mother's education, as measured by two dummy-variables indicating high-school degree and university degree. The variable indicating university degree is also interacted with a dummy variable indicating that the child is under the age of three, since high skill mothers may wish to enter the labour market earlier and therefore demand a child care slot earlier than lower skilled mothers. Further, a hypothetical net household income is used that measures net household income in the case that the mother is not working. This income is calculated on the basis of the tax-benefit simulation model STSM (see Steiner et al. 2005) and contains the household's capital income, income from rent and lease and the earned incomes of other household members as well as public transfers such as social assistance, if the household is eligible. This hypothetical net income is used rather than the actual household income, since actual income is potentially endogenous (the decision of the mother to work might be correlated with demand for child care slots). I also think that it is more appropriate to use the hypothetical net household income rather than the actual "other income" (i.e. husband's labor income, social transfers, income from capital, rent and lease etc.). Under the German tax-transfer regulations, which include joint taxation of married couples and many means-tested benefits on the household level, the level of "other income" is also influenced by the mother's employment decision.

A dummy variable indicating frequent church attendance of the mother is also used as a variable that possibly captures attitudes towards non-parental child care. In 
addition to these mother's characteristics and income variables, some variables on household composition are also included in the estimation of the demand equation, such as number of siblings in certain age groups and the presence of another adult household member besides the parents.

In the supply equation, the number of child care slots per child available at the county level is used as an additional explanatory variable. This variable is available for each of the 440 counties and for two different age groups, namely for children under the age of three and for children aged between three and school age.

Chevalier and Viitanen (2004) also use the average price for a child care facility at the regional level for identification of the demand equation. For the case of Germany, this variable cannot be used. Official data on prices at the regional level do not exist since facilities are not required to report the prices they charge. However, even if data on parents' fees were available, it would not be possible to include them as explanatory variable in the estimation of the demand equation due to endogeneity problems. This is because the parents' fees depend on the family's income, which is determined by employment of both parents. As has been argued before, mothers' labor force participation is endogenous. Thus, in the German context, it is not possible to control for prices in the demand equation.

\section{Data and Variables}

The model described in the section above will be estimated on the basis of data from the German Socio-Economic Panel (SOEP) from the year 2002. The SOEP is a representative panel study of private households living in Germany. ${ }^{12}$ While the SOEP usually contains only basic information on child care utilization, the 2002 wave provides detailed information on child care utilization, type of facility, child

\footnotetext{
${ }^{12}$ For more information on the SOEP, see http://www.diw.de/english/sop/.
} 
care hours, expenditures and informal care arrangements. The 2001 wave of the SOEP is used to get information about last year's child care status.

As already mentioned in the section above, for the estimation of the model, regional information on the county level is matched to the individual data. ${ }^{13}$ Child care availability ratios (child care slots per child in each county) for two different age groups are matched to the individual child information from the SOEP. These data were provided by the German Youth Institute (Deutsches Jugendinstitut DJI). ${ }^{14}$ Additionally, data on the spatial structure of the counties are matched to the individual data using variables from the INKAR data set provided by the Federal Office for Building and Regional Planning (Bundesamt für Bauwesen und Raumordnung). ${ }^{15}$ In this data set, all 440 German counties are classified into 1 out of 9 spatial structure types, depending on population density and distance to the next urban centre. Tables 2 and 3 provide detailed information on sample size, definitions and descriptive statistics on the variables used in the estimated model.

[Table 2 about here]

[Table 3 about here]

\section{Estimation Results}

Table 4 presents the coefficients of the estimated model. All coefficients - if significant - have the expected sign. The demand for child care is positively influenced by the age of the child, by the simulated net household income and the number of siblings who are attending child care facilities. More educated mothers demand more child care for their children, although the coefficient for "mother

\footnotetext{
${ }^{13}$ I thank DIW Berlin for the special permission to use the regional code number at the county level.

${ }^{14}$ I would like to thank H. Bayer from the Deutsches Jugendinstitut for the provision of this data.

${ }^{15}$ For more information on these data, see Bundesamt für Bauwesen und Raumordnung (2002).
} 
holding a university degree" is significant only for children under three years. ${ }^{16}$ The mother's nationality does not influence the demand for child care, however the frequency of her church attendance has a significantly negative effect on the demand for child care. The same is true for the number of siblings and the presence of another adult household member apart from the parents. While the size of the city does not have a significant effect on the demand for child care, living in east Germany leads to a significantly higher demand than living west Germany.

In the supply equation, the availability of child care slots on the county level has a positive influence on the individual probability of being offered a child care slot. The age of the child also has a positive effect. The mother's marital status does not influence the probability of being offered a slot. This is also true for the number of siblings already in child care. However, the mother's nationality does affect the probability of being offered a child care slot: German mothers are more likely to have access to child care services than non-German mothers. This might either be an indication for discrimination by the providers of child care services, or for the fact that for non German parents, it might be more difficult to overcome access restrictions to child care due to communication problems, lack of knowledge concerning official or unofficial channels, etc. Neither the regional variables nor the variable indicating rural area are statistically significant. This is not surprising since differences in the provision of child care slots are already captured by the 'availability of child care slots' variable. The correlation coefficient of the error terms of the demand and supply equations (rho) is positive yet not significant.

[Table 4 about here]

\footnotetext{
${ }^{16}$ This result is not surprising since child care utilization for children older than three years is common in Germany even for children with non-working mothers (see section 2).
} 
In order to asses the predictive quality of the estimated model, I compare actual and predicted values of child care utilization. The predicted value is coded as 1 if the predicted probability is higher than 0.5 . The model performs well in predicting the joint outcome of child care demand and supply. As Table 5 shows, 90 percent of all observations are predicted correctly according to this rule. For comparison, a model that explains the left-hand side variable by a constant only would predict 54 percent of all cases correctly.

Estimations from the partial observability model allow to predict the marginal probabilities of demand for and supply of child care slots. Table 5 shows these marginal probabilities by regions and age groups. For all age groups, demand for a child care slot is lower in west than in east Germany. The predicted probabilities of supply of child care slots come close to the official statistics on availability. However, especially for children younger than three years living in west Germany, the marginal probability of being offered a slot is higher than the official availability ratio. This might be explained by the fact that child care facilities are willing to take more than one child per slot and that - at least in some regions - there might actually be more slots available within the family day care system than reported by official statistics.

[Table 5 about here]

The joint probability that parents demand child care for a child but are not offered a slot gives the individual probability of being rationed. These probabilities are presented in Table 6 by age group and region. Although availability of child care slots is much higher in east than in west Germany for children in the younger age group, excess demand for child care is more prevalent in the east. This result is surprising yet can be explained by the fact that not only the supply but also the 
demand for child care in east Germany is well above the level in west Germany. For children in the older age group, access restrictions to child care seem to be only a minor problem. ${ }^{17}$

[Table 6 about here]

As Table 6 shows, excess demand for child care is quite large for children in the younger age group even when only the sample of children with working mothers is considered. Since employment status of the mother is not included as an explanatory variable, these numbers have to be seen as an upper bound for the excess demand for subsidized child care of children with working mothers. Usually, in Germany child care facilities favour children with working mothers; this effect could not be explicitly taken into account in the empirical analysis.

The total size of the queue for child care slots in numbers of children is shown in Table 7. In total, parents of more than 600,000 children up to the age of three years demand subsidized child care but are not offered a slot. Most of these children have non-working mothers, as is shown in Table 8. However, more than 200,000 slots would be needed only for children of employed mothers, including those with mothers in marginal employment. Another 20,000 children who are queuing have mothers who state that they intend to start working "as soon as possible". ${ }^{18}$ Note that these numbers are probably the lower-bound of mothers with small children stating that they wish to work in the near future, since they are not

\footnotetext{
${ }^{17}$ It should be noted, however, that rationing of child care services has more than one dimension: in addition to access restrictions to child care services, short opening hours, e.g. only in the morning, also poses a problem in many regions of Germany. This is particularly true for children between three and six years. This dimension of rationing has not been studied in this analysis.

${ }^{18}$ In the SOEP questionnaire, non-working persons are asked "Do you intend to engage in paid employment (again) in the future?". The possible answer categories to this questions are "No, definitely not", "Probably not", "Probably" and "Yes, definitely". After that, people are asked "When, approximately, would you like to start with paid employment?", and the possible answers are "As soon as possible", "Next year", "In the next two to five years" and "In the distant future, in more than five years".
} 
explicitly asked if they intend to work provided they could be offered a child care slot.

[Table 7 about here]

[Table 8 about here]

The high number of children with working mothers queuing for child care slots suggests to target public expenditures towards providing child care primarily for this group. However, the positive outcomes of child care on later educational achievements (see Rossbach 2005) might be one reason to subsidize child care independently of the labor force status of their parents.

\section{Summary and Conclusions}

In this paper, I have estimated the excess demand for public child care in Germany on the basis of a partial observability model. The model developed here makes use of the advantages of the models proposed by Poirier (1980) and Abowd and Farber (1982). Since it is known that certain children are not restricted in their access to child care facilities, the sample could be divided into two parts, into children not restricted and children who might be restricted. The estimation of demand and supply of child care slots is based on a likelihood function that consists of two parts, a univariate probit of the demand for child care for the unrestricted part of the sample and a bivariate probit of demand and supply of child care for the possibly restricted part of the sample.

Estimation results show that among children aged up to three, a large fraction is queuing for child care ( 24 percent in west Germany and 59 percent in east Germany), i.e. their parents demand child care services but there is no slot available. Excess demand for subsidized child care is also present among children with 
working mothers. This would suggest that, as far as public policy is concerned, public expenditures should be concentrated on the provision of child care for this group. This has in fact been reflected in legislation recently passed by the German parliament.

The relevance of the results presented here, however, goes beyond the current political debate in Germany. Since several European countries (e.g. Austria, Switzerland, Italy and other southern European countries) have similar child care institutions as (west) Germany, the results presented here suggest that excess demands for child care exists also in these countries. Furthermore, the results for east Germany suggest that excess demand for child care might also exist in transition economies where public expenditures for child care have been cut, even though the availability of child care might still be higher than in many western European countries. 
Acknowledgements: This research project was funded by the Thyssen Foundation in the research project "Labor Market and Welfare Effects of Family Policy in Germany". I would like to thank M. Csillag, P. Haan, C. Langer, M. Myck, C. K. Spiess, V. Steiner, A. Uhlendorff and T. Viitanen, as well as participants of the "Berlin Network of Labour Market Research" seminar for helpful comments and discussions on an earlier draft. The usual disclaimer applies. 


\section{References}

ABowd, John M. and Henry S. FARBER (1982): Job Queues and the Union Status of Workers, Industrial and Labor Relations Review Vol. 35/3: 354-367.

BMFSFJ (German Ministry for Families, Seniors, Women and Youth) (ed.) (2003): Die Familie im Spiegel der amtlichen Statistik. Berlin.

BÜCHEL, Felix and C. Katharina SPIEß (2002): Form der Kinderbetreuung und Arbeitsmarktverhalten von Müttern in West- und Ostdeutschland. Schriftenreihe des BMFSFJ, Vol. 220. Kohlhammer: Stuttgart.

BUNDESAMT FÜR BAUWESEN UND RAUMORDNUNG (2002): Aktuelle Daten zur Entwicklung der Städte, Kreise und Gemeinden. Bonn.

Chevalier, Arnaud and Tarja ViITANEN (2004): The Supply of Childcare in Britain: Do Mothers Queue for Childcare? Mimeo.

Choné, Philippe, David Le Blanc and Isabelle RoBert-BobÉE (2003): Female Labor Supply and Child Care in France. CESifo Working Paper No. 1059.

ConNelly, Rachel, and Jean Kimmel (2003): Marital Status and Full-time/part-time Work Status in Child Care Choices, Applied Economics Vol. 35: 761-777.

Del BocA, Daniela, Marilena Locatelli and Daniela Vuri (2004): Child Care Choices by Italian Households, IZA Discussion Paper No. 983.

DJI (Deutsches Jugendinstitut) (2002): Zahlenspiegel. Daten zu Tageseinrichtungen für Kinder. München.

EVERS, Adalbert, Jane LEWIS and Brigit RIEDEL (2005): Developing child-care provision in Endland and Germany: problems of governance, Journal of European Social Policy Vol. 15: 195-209.

JoEsCH, Jutta M. and Bridget G. Hiedemann (2002): The demand for nonrelative child care among families with infants and toddlers: A double-hurdle approach, Journal of Population Economics Vol. 15: 495-526.

JuRCZYK, Karin, Thomas RAuschenBACH and Wolfgang TIETZE (ed) (2004): Von der Tagespflege zur Familientagesbetreuung. Zur Zukunft öffentlich regulierter Kinderbetreuung in Privathaushalten. Beltz:Weinheim and Basel. 
Kornstad, Tom and Thor O. THOREnsen (2005): A Discrete Choice Model for Labor Supply and Child Care. Journal of Population Economics, forthcoming.

LAUER, Charlotte and Andrea M. WEBER (2003): Employment of Mothers after Childbirth: A French-German Comparison. ZEW Discussion Paper No. 03-50.

LOKSHIN, Michael (2004): Household Childcare Choices and Women's Work Behavior in Russia, The Journal of Human Resources Vol. 39/4: 1094-1115.

Media-Forschung Und -SERVICE (2004): Mehr Kinder. Mehr Leben. Ergebnisse der repräsentativen Forsa-Befragung. Mimeo.

MERKLE, Lucie E. (1994): Frauenerwerbstätigkeit und Kinderbetreuung. Eine theoretische und empirische Analyse für die Bundesrepublik Deutschland. PhysicaVerlag: Heidelberg.

ONDRICH, Jan and C. Katharina SPIEß (1998): Care of Children in a Low Fertility Setting: Transitions between Home and Market Care for Pre-School Children in Germany, Population Studies, Vol. 52/1: 35-48.

Plantenga, Janneke (2004): Investing in childcare. The Barcelona childcare targets and the European social model. Speech prepared for the conference: Child care in a changing world, 21-23 October 2004, Groningen.

POIRIER, Dale J. (1980) : Partial Observability in Bivariate Probit Models, Journal of Econometrics Vol. 12: 209-217.

Rosenfeld, Rachel A., Heike TrapPE and Janet C. Gornick (2004): Gender and Work in Germany: Before and After Reunification, Annual Review of Sociology Vol. 30: $103-124$.

RossBACH, Hans-Günther (2005): Effekte qualitativ guter Betreuung, Bildung und Erziehung im frühen Kindesalter auf Kinder und ihre Familien. In:

Sachverständigenkommission Zwölfter Kinder- und Jugendbericht (Ed.): Bildung, Betreuung und Erziehung von Kindern unter sechs Jahren. Materialien zum 12. Kinder- und Jugendbericht.

Steinbach, Anja (2004): Wie Paare sich die Arbeit teilen. In: Fthenakis, Wassilios E. and Textor, Martin E. (ed.): Das Online-Familienhandbuch.

STEINER, Viktor and and Katharina WrOHLICH (2004): Household Taxation, Income Splitting and Labor Supply Incentives - A Microsimulation Study for Germany, CESifo Economic Studies Vol. 50: 541-568. 
STEINER, Viktor, Peter HAAN and Katharina WrOHLICH (2005): Documentation of the Tax-Benefit-Microsimulation Model STSM (1999-2002). Mimeo.

STÖBE-BLOSSEY, Sybille (2004): Bedarfsorientierte Kinderbeteruung. Teil 1: Arbeitszeit und Infrakstruktur. Vorläufige Auswertung einer Befragung von Müttern mit Kindern unter 14 Jahren. Arbeitspapier des Instituts Arbeit und Technik, Gelsenkirchen.

StUTZER, Alois and Reto DuERSTELER (2005): Versagen in der staatlichen Krippenförderung - Betreuungsgutscheine als Alternative. CREMA Working Paper No. 2005-26. 
Tables and Figures

Figure 1: Publicly financed/subsidized child care slots for children aged less than three per hundred children in selected countries of the European Union

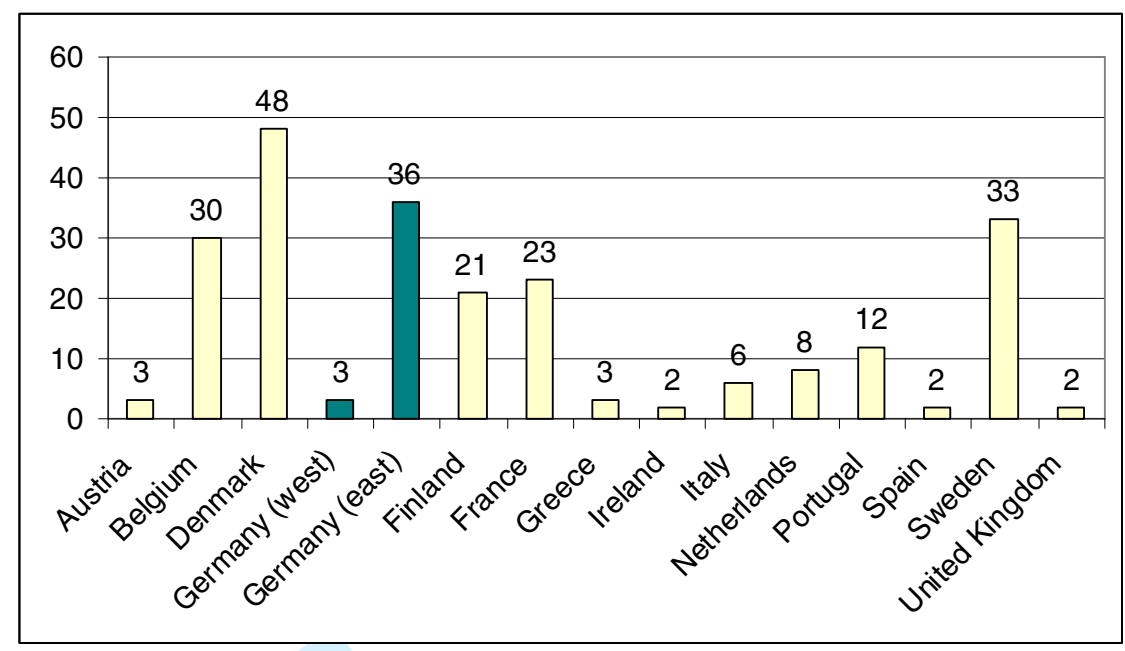

Source: BMFSFJ (2003) and DJI (2002).

Table 1: Child care utilization and employment of mothers with young children in Germany

\begin{tabular}{|c|c|c|c|c|}
\hline \multicolumn{5}{|c|}{ Official statistics on availability of child care slots (slots per 100 children) } \\
\hline & \multicolumn{2}{|c|}{ Children aged $0-<3$} & \multicolumn{2}{|c|}{ Children aged 3-6 } \\
\hline$\overline{\text { All }}$ & \multicolumn{2}{|c|}{$8 \%$} & \multicolumn{2}{|c|}{$105 \%$} \\
\hline East Germany & \multicolumn{2}{|c|}{$33 \%$} & \multicolumn{2}{|c|}{$115 \%$} \\
\hline \multirow[t]{3}{*}{ West Germany } & \multicolumn{2}{|c|}{$3 \%$} & \multicolumn{2}{|c|}{$104 \%$} \\
\hline & \multicolumn{2}{|c|}{$\begin{array}{l}\text { Child care utilization } \\
\text { (only child care } \\
\text { in subsidized facilities) }\end{array}$} & \multicolumn{2}{|c|}{$\begin{array}{l}\text { Employment of mother } \\
\text { (all children) }\end{array}$} \\
\hline & $\begin{array}{c}\text { Children aged } \\
0-<3\end{array}$ & $\begin{array}{c}\text { Children aged } \\
3-6\end{array}$ & $\begin{array}{c}\text { Children aged } \\
0-<3\end{array}$ & $\begin{array}{c}\text { Children aged } \\
3-6\end{array}$ \\
\hline All & $10 \%$ & $84 \%$ & $21 \%$ & $37 \%$ \\
\hline East Germany & $32 \%$ & $92 \%$ & $37 \%$ & $50 \%$ \\
\hline \multirow[t]{4}{*}{ West Germany } & $6 \%$ & $82 \%$ & $18 \%$ & $34 \%$ \\
\hline & \multicolumn{4}{|c|}{ Employment of mother } \\
\hline & \multicolumn{2}{|c|}{ Children in child care } & \multicolumn{2}{|c|}{ Children not in child care } \\
\hline & $\begin{array}{c}\text { Children aged } \\
0-<3\end{array}$ & $\begin{array}{c}\text { Children aged } \\
3-6\end{array}$ & $\begin{array}{c}\text { Children aged } \\
0-<3\end{array}$ & $\begin{array}{c}\text { Children aged } \\
3-6\end{array}$ \\
\hline$\overline{\text { All }}$ & $58 \%$ & $39 \%$ & $17 \%$ & $23 \%$ \\
\hline East Germany & $69 \%$ & $54 \%$ & $17 \%$ & $0 \%$ \\
\hline West Germany & $46 \%$ & $37 \%$ & $16 \%$ & $24 \%$ \\
\hline
\end{tabular}

Note: Employment of Mother means full-time or part-time employment. Marginal employment ("geringfuegige Beschaeftigung") is not included.

Source: SOEP, wave 2002 and DJI 2002. 
Table 2: Sample description

\begin{tabular}{l|c}
\hline $\begin{array}{l}\text { Number of children in SOEP wave 2002, } \\
\text { aged } \mathbf{0}-\mathbf{6} \text { and not yet enrolled in school } \\
\text { (... these children live in } 1426 \text { households) }\end{array}$ & 1857 \\
\hline $\begin{array}{l}\text { Observations lost due to missing values in the variable on local availability of } \\
\text { child care facilities }\end{array}$ & 27 \\
\hline $\begin{array}{l}\text { Observations lost due to missing values in the hypothetical net household } \\
\text { income variable* }\end{array}$ & 20 \\
\hline Sample size used for estimation & $\mathbf{1 8 1 0}$ \\
\hline$\ldots$ thereof children who are not constrained in their access to childcare & 907 \\
\hline$\ldots$ children who might be constrained & 891 \\
\hline
\end{tabular}

* In these cases, there were missing values on variables needed for the calculation of net household income, such as missing information on the income of other household members.

Source: SOEP, wave 2002.

Table 3: Variable description

\begin{tabular}{|c|c|c|c|}
\hline Variable Name & Description & Mean & $\begin{array}{l}\text { Standard } \\
\text { Deviation }\end{array}$ \\
\hline \multicolumn{4}{|l|}{ Dependent variable } \\
\hline \multirow{3}{*}{ inchildcare } & Dependent variable: 1 if child is in child care facility ${ }^{\top}$ & 0.54 & -- \\
\hline & ...mean in the "not constrained" part of the sample & 0.92 & -- \\
\hline & $\begin{array}{l}\text {...mean in the "might be constrained" part of the } \\
\text { sample }\end{array}$ & 0.17 & -- \\
\hline \multicolumn{4}{|c|}{ Explanatory variables used in both equations } \\
\hline age01 & Dummy variable: 1 if child is aged 0 or $1^{2}$ & 0.26 & -- \\
\hline age2 & Dummy variable: 1 if child is aged $2^{2}$ & 0.16 & -- \\
\hline age3 & Dummy variable: 1 if child is aged $3^{2}$ & 0.16 & -- \\
\hline dadyes & Dummy variable: 1 if mother is married or cohabiting & 0.91 & -- \\
\hline german_mother & Dummy-Variable: 1 if mother has German nationality & 0.84 & -- \\
\hline numsiblcc_03 & Number of siblings aged $0-3$ in child care facility & 0.08 & 0.32 \\
\hline numsiblcc_46 & Number of siblings aged 4-6 in child care facility & 0.18 & 0.44 \\
\hline \multicolumn{4}{|c|}{ Explanatory variables used in the demand equation only } \\
\hline highschool_mother & Dummy-Variable: 1 if mother holds high-school degree & 0.23 & -- \\
\hline university_mother & Dummy-Variable: 1 if mother holds university degree & 0.10 & -- \\
\hline german_mother & Dummy-Variable: 1 if mother has German nationality & 0.84 & -- \\
\hline otheradult & $\begin{array}{l}\text { Dummy-Variable: } 1 \text { if there is an adult living in the } \\
\text { household apart from father and mother }\end{array}$ & 0.06 & -- \\
\hline hyp_netincome & $\begin{array}{l}\text { hypothetical net monthly household income if mother's } \\
\text { working hours are zero, divided by } 1,000\end{array}$ & 2.63 & 1.29 \\
\hline sibls03 & Number of siblings between 0 and 3 years & 0.21 & 0.42 \\
\hline sibls46 & Number of siblings between 4 and 6 years & 0.20 & 0.41 \\
\hline sibls610 & Number of siblings between 6 and 10 years & 0.26 & 0.47 \\
\hline sisters1016 & Number of sisters between 10 and 16 years & 0.08 & 0.27 \\
\hline church & $\begin{array}{l}\text { Dummy-Variable: } 1 \text { if mother reports to attend church } \\
\text { or other religious events every week or every month }\end{array}$ & 0.20 & -- \\
\hline
\end{tabular}


Table 3 continued

\begin{tabular}{l|lll}
\hline \multicolumn{6}{l}{ Explanatory variables used in the supply equation only } & & \\
\hline availability & $\begin{array}{l}\text { Availability ratios of child care slots by age group on the } \\
\text { local level: Number of child care slots per child }\end{array}$ & 0.66 & 0.50 \\
\hline Regional and spatial structure variables, used in both equations & & \\
\hline region1 & $\begin{array}{l}\text { Dummy: } 1 \text { if child lives in Schleswig-Holstein, Lower } \\
\text { Saxony, Hamburg or Bremen }\end{array}$ & 0.15 & -- \\
\hline region2 & $\begin{array}{l}\text { Dummy: } 1 \text { if child lives in Hesse, Rhineland-Palatinate } \\
\text { or Saarland }\end{array}$ & 0.17 & -- \\
\hline region3 & Dummy: 1 if child lives in Northrhine-Westfalia & 0.22 & -- \\
\hline region4 & Dummy: 1 if child lives in Baden-Wurttemberg & 0.15 & -- \\
\hline region5 & Dummy: 1 if child lives in Bavaria ${ }^{3}$ & 0.14 & -- \\
\hline rural & Dummy: 1 if county is a rural area & 0.12 & -- \\
\hline \hline
\end{tabular}

${ }^{1}$ This variable is not coded as 1 if parents report the child being cared for by a childminder ("Tagesmutter").

2 Base category of age dummies are children aged 4, 5 or 6 and not yet enrolled in school. The exact age of each child at the time of the interview is calculated by using information on the month of birth and the month of the interview.

${ }^{3}$ Base Category: if child lives in one of the federal states in east Germany, i.e. Berlin, MecklenburgWestern Pomerania, Brandenburg, Saxony-Anhalt, Saxony and Thuringia.

Source: SOEP, wave 2002. 
Table 4: Estimation results

\begin{tabular}{|c|c|c|c|c|}
\hline \multirow[b]{2}{*}{ Variable } & \multicolumn{2}{|c|}{ Demand Equation } & \multicolumn{2}{|c|}{ Supply Equation } \\
\hline & Coefficient & Standard Error* & Coefficient & Standard Error ${ }^{*}$ \\
\hline age01 & -3.01 & 0.92 & -1.61 & 0.69 \\
\hline age2 & -3.32 & 0.65 & -0.38 & 0.72 \\
\hline age3 & -1.29 & 0.18 & -0.80 & 0.35 \\
\hline dadyes & -0.10 & 0.24 & -0.03 & 0.40 \\
\hline german_mother & -0.23 & 0.22 & 0.65 & 0.30 \\
\hline numbersiblscc_03 & 3.60 & 6.86 & -0.04 & 0.28 \\
\hline numbersiblscc_46 & 1.00 & 0.40 & -0.09 & 0.19 \\
\hline "highschool_mother & 0.58 & 0.19 & & \\
\hline university_mother & -0.33 & 0.26 & -- & -- \\
\hline university_age03 & 1.73 & 0.76 & & \\
\hline hyp_netincome & 0.16 & 0.07 & & \\
\hline siblings03 & -0.68 & 0.17 & -- & -- \\
\hline siblings46 & -0.96 & 0.32 & -- & -- \\
\hline siblings610 & -0.46 & 0.13 & -- & -- \\
\hline sisters1016 & -0.62 & 0.20 & -- & -- \\
\hline otheradult & -0.50 & 0.23 & -- & -- \\
\hline church & -0.28 & 0.16 & -- & -- \\
\hline age_u3_east & 2.46 & 0.75 & -- & -- \\
\hline availability & -- & -- & 1.61 & 0.75 \\
\hline region1 & $\begin{array}{c}-0.70 \\
\end{array}$ & 0.27 & -0.32 & 0.50 \\
\hline region2 & -0.20 & 0.26 & -0.20 & 0.45 \\
\hline region3 & -0.35 & 0.30 & -0.12 & 0.37 \\
\hline region4 & -0.27 & 0.26 & 0.12 & 0.50 \\
\hline region5 & -0.46 & 0.27 & -0.37 & 0.39 \\
\hline rural & -0.08 & 0.20 & 0.31 & 0.27 \\
\hline constant & 2.45 & 0.38 & -0.63 & 0.97 \\
\hline rho & 0.16 & 0.52 & & \\
\hline
\end{tabular}

Number of observations: 1810

Log likelihood: -436.41

Wald chi2 (24): 129.70

Percent correctly predicted:

\begin{tabular}{l|l|l|l|l|}
\hline \multicolumn{2}{c|}{} & \multicolumn{2}{|c|}{ Actual } & \\
\cline { 3 - 4 } \multicolumn{2}{c|}{} & \multicolumn{1}{|c}{0} & 1 & \\
\multirow{2}{*}{ Predicted } & 0 & $729(40 \%)$ & $88(5 \%)$ & \\
\cline { 2 - 4 } & 1 & $97(5 \%)$ & $896(50 \%)$ & \\
\hline
\end{tabular}

* Robust Standard Errors.

Source: Estimations based on SOEP, wave 2002. 
Table 5: Marginal probabilities of demand for and supply of childcare slots

\begin{tabular}{l|cc|cc}
\hline & \multicolumn{2}{|c|}{ Age group $\mathbf{0}-<3$} & \multicolumn{2}{c}{ Age group 3-6 } \\
\hline & $\mathbf{P}($ Demand=1) & $\mathbf{P}($ Supply=1) & $\mathbf{P}$ (Demand=1) & $\mathbf{P ( S u p p l y = 1 )}$ \\
\hline East & 0.96 & 0.39 & 0.93 & 0.99 \\
Germany & $(0.84-0.98)$ & $(0.34-0.44)$ & $(0.76-0.95)$ & $(0.98-0.99)$ \\
\hline West & 0.28 & 0.14 & 0.89 & 0.94 \\
Germany & $(0.09-0.59)$ & $(0.09-0.23)$ & $(0.80-0.90)$ & $(0.92-0.96)$ \\
\hline
\end{tabular}

Numbers in brackets refer to $95 \%$ confidence interval calculated using the bootstrap method.

Source: Estimations based on SOEP, wave 2002.

Table 6: Probability of being rationed, by age group and regions as well as working status of the mother

\begin{tabular}{|c|c|c|}
\hline 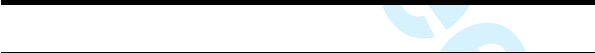 & Age group $0-<3$ & Age group 3-6 \\
\hline East Germany & $\begin{array}{c}0.59 \\
(0.48-0.64) \\
\end{array}$ & $\begin{array}{c}0.01 \\
(0.00-0.01) \\
\end{array}$ \\
\hline West Germany & $\begin{array}{c}0.24 \\
(0.06-0.55) \\
\end{array}$ & $\begin{array}{c}0.04 \\
(0.02-0.06) \\
\end{array}$ \\
\hline \multicolumn{3}{|l|}{$\begin{array}{l}\text { Children with full-time or part-time } \\
\text { working mothers }\end{array}$} \\
\hline East Germany & $\begin{array}{c}0.40 \\
(0.32-0.45)\end{array}$ & $\begin{array}{c}0.00 \\
(0.00-0.01)\end{array}$ \\
\hline West Germany & $\begin{array}{c}0.26 \\
(0.09-0.56)\end{array}$ & $\begin{array}{c}0.03 \\
(0.01-0.04)\end{array}$ \\
\hline Children with non-working mothers & & \\
\hline East Germany & $\begin{array}{c}0.66 \\
(0.54-0.71)\end{array}$ & $\begin{array}{c}0.01 \\
(0.00-0.02)\end{array}$ \\
\hline West Germany & $\begin{array}{c}0.23 \\
(0.06-0.55) \\
\end{array}$ & $\begin{array}{c}0.05 \\
(0.03-0.07) \\
\end{array}$ \\
\hline
\end{tabular}

Numbers in brackets refer to $95 \%$ confidence intervals calculated using the bootstrap method.

Source: Estimations based on SOEP, wave 2002. 
Table 7: Number of children queuing for childcare, in thousands (rounded)

\begin{tabular}{l|rc|}
\hline & Age group 0 - <3 & Age group 3-6 \\
\hline \multirow{2}{*}{ east Germany } & 210 & 5 \\
& $(167-229)$ & $(2-9)$ \\
\hline \multirow{2}{*}{ West Germany } & 431 & 106 \\
& $(118-941)$ & $(65-155)$ \\
\hline \hline
\end{tabular}

Numbers in brackets refer to $95 \%$ confidence interval calculated using the bootstrap method. Source: Estimations based on SOEP, wave 2002.

Table 8: Number of children under 3 years queuing for subsidized child care, by employment status / intention of the mother, in thousands (rounded)

\begin{tabular}{l|cr}
\hline & East Germany & West Germany \\
\hline Mother working full-time or part-time & 42 & 93 \\
& $(31-48)$ & $(37-178)$ \\
\hline Mother in marginal employment & 6 & 64 \\
& $(5-7)$ & $(10-113)$ \\
\hline Mother intends to start working "as soon as possible" * & 2 & 16 \\
\hline Mother intends to start working "next year" * & $(0-2)$ & $(6-30)$ \\
\hline Mother in none of the above categories & 60 & 40 \\
& $(48-64)$ & $(5-104)$ \\
\hline
\end{tabular}

* Only those mothers were considered who answered "Yes, definitely" to the question "Do you intend to engage in paid employment (again) in the future?"

Numbers in brackets refer to $95 \%$ confidence intervals calculated using the bootstrap method.

Source: Estimations based on SOEP, wave 2002. 